\title{
KRAS Gene Amplification
}

National Cancer Institute

\section{Source}

National Cancer Institute. KRAS Gene Amplification. NCI Thesaurus. Code C36665.

A molecular genetic abnormality indicating the presence of multiple copies of the KRAS gene. 